\title{
Influence of Groundnut bud necrosis virus on the Life History Traits and Feeding Preference of Its Vector, Thrips palmi
}

\author{
Guisuibou Daimei, Harpreet Singh Raina, Pukhrambam Pushpa Devi, Gunjan Kumar Saurav, Perumal Renukadevi, \\ Varagur Ganesan Malathi, Chinnaiah Senthilraja, Bikash Mandal, and Raman Rajagopal ${ }^{\dagger}$
}

First, third, fourth, and ninth authors: Department of Zoology, University of Delhi, Delhi-110007, India; second author: Department of Zoology and Department of Zoology, Sri Guru Tegh Bahadur Khalsa College, University of Delhi; fifth, sixth, and seventh authors: Centre for Plant Protection Studies, Department of Plant Pathology, Tamil Nadu Agricultural University, Coimbatore-641003, Tamil Nadu, India; and eighth author: Advanced Centre for Plant Virology, Division of Plant Pathology, Indian Agricultural Research Institute, New Delhi-110012, India. Accepted for publication 8 June 2017.

\begin{abstract}
The effect of Groundnut bud necrosis virus (GBNV) infection on the life history traits of its vector, Thrips palmi, and its feeding preference on GBNV-infected plants were studied. A significant difference was observed in the developmental period (first instar to adult) between the GBNV-infected and healthy thrips, wherein the developmental period of GBNV-infected

investigation on a settling and feeding choice assay of T. palmi to GBNVinfected and healthy plants showed that $T$. palmi preferred GBNV-infected cowpea plants more than the healthy cowpea plants. This preference was also noticed for leaf disks from GBNV-infected cowpea, groundnut, and tomato plants.
\end{abstract} thrips was decreased. However, there was no effect on the other parameters such as preadult mortality, adult longevity, and fecundity. Further
Additional keywords: tospovirus, virus-vector interaction.
Most plant viruses (76\%) are reported to be vector borne, and the majority $(55 \%)$ are transmitted by insects belonging to hemipteran groups such as aphids and whiteflies as well as thrips (order Thysanoptera) (Hogenhout et al. 2008). Crop plants can be affected directly by thrips through feeding injuries (Childers and Achor 1995; Childers and Bullock 1999; Heming 1993; Lewis 1973) and also indirectly by transmitting plant viruses (Riley et al. 2011). Among the many plant viruses transmitted by insects, tospoviruses are transmitted exclusively by several thrips species (Riley et al. 2011). Thrips-borne tospoviruses damage several economically important crops and ornamental plants, causing significant economic losses throughout the world (Belliure et al. 2005; Culbreath et al. 2003; Goldbach and Peters 1994; Jones 2005; Pappu et al. 2009; Pearce 2005; Persley et al. 2006; Riley et al. 2011; Rotenberg et al. 2015; Whitfield et al. 2005; Wijkamp et al. 1996). In Asia, Groundnut bud necrosis virus (GBNV) is considered to be the most economically important Tospovirus sp. that affects several vegetable crops and ornamental plants. It is estimated that GBNV alone causes more than U.S.\$89 million losses annually (Reddy et al. 1995). It has been reported that GBNV causes more than 70 to $90 \%$ yield loss in peanut (Singh and Srivastava 1995), and up to $29 \%$ yield loss on potato in India (Singh et al. 1997). Furthermore, GBNV has been reported to affect several other important crops such as soybean (Bhat et al. 2002), pea (Akram and Naimuddin 2010), mungbean (Jain et al. 2002; Thien et al. 2003), cowpea (Jain et al. 2002), and tomato (Jain et al. 2002; Raja and Jain 2006). Recently a new tospovirus, Soybean vein necrosis virus (SVNV), transmitted by Neohydatothrips variabilis, was found to be an emerging virus on soybean and is widespread in the United States (Keough et al. 2016).

In nature, tospoviruses are transmitted by several thrips species in a propagative and persistent manner from one plant to another

${ }^{\dagger}$ Corresponding author. E-mail: zoorajagopal@gmail.com

(C) 2017 The American Phytopathological Society
(Birithia et al. 2013; Inoue et al. 2010; Sherwood et al. 2000; Ullman et al. 1993; Whitfield et al. 2005; Wijkamp et al. 1993). The uniqueness of the thrips-tospovirus relationship is that only the adult thrips and, in part, the second-instar larvae can transmit the virus, if acquisition occurs during the first-instar larval stage (Moritz et al. 2004; Ullman et al. 1992). After acquisition, the virus initially infects the midgut epithelium and then infects the surrounding muscles, subsequently reaching the salivary glands. The virus further replicates in the salivary gland and finally gets transmitted to healthy plants through saliva during the feeding process (Moritz et al. 2004; Ullman et al. 1992).

Tospoviruses not only infect plants but also affect their vectors by replicating in the midgut and other parts of the insect body (Birithia et al. 2013; German et al. 1992; Moritz et al. 2004; Tsuda et al. 1996; Ullman et al. 1992; Wijkamp et al. 1993). It is believed that the infection of Tospovirus spp. on vector species is likely to cause behavioral and other physiological changes that influence the overall fitness and performance of the vector. It has also been reported that Tomato spotted wilt virus (TSWV) and Iris yellow spot virus (IYSV) replicate inside the vector species (Birithia et al. 2013; Wijkamp et al. 1993) and, thus, thrips also serve as a virus host. Several studies have been conducted which showed that plant virus infection alters the fitness of the vector. It has been shown that virus also modifies the feeding behavior of the vector, such that TSWVexposed Frankliniella occidentalis thrips fed more than their healthy counterparts (Ogada and Poehling 2015) and F. occidentalis male thrips infected with TSWV fed more than uninfected males (Stafford et al. 2011). In contrast, in one study, nonviruliferous $F$. fusca fed more than TSWV-infected F. fusca (Shrestha et al. 2012). Plant viruses have also been reported to increase or decrease fecundity (Jiu et al. 2007; Keough et al. 2016; Ogada et al. 2013; Shrestha et al. 2012), mortality (Ogada and Poehling 2015; Ogada et al. 2013; Stumpf and Kennedy 2005, 2007), developmental period (Ogada and Poehling 2015; Shrestha et al. 2012; Stumpf and Kennedy 2005, 2007), and longevity of their vectors (Inoue and Sakurai 2006; Jiu et al. 2007; Ogada and Poehling 2015; Ogada et al. 2013). They also affect morphological characteristics of their vector 
such as reducing head capsule size in adults (Stumpf and Kennedy 2005, 2007). The conflicting results that have been reported with regards to effects of tospoviruses on their vector fitness parameters might have resulted due to the use of different Tospovirus isolates, vector species, population, and associated host plants in addition to different experimental conditions (Jacobson and Kennedy 2013; Stumpf and Kennedy 2007).

Most studies on Tospovirus spp. and their vector species have been carried out on TSWV and $F$. occidentalis. Many reports have shown the effects of different tospoviruses on their thrips vector, such as TSWV on F. occidentalis (Ogada et al. 2013); F. fusca (Shrestha et al. 2012), T. tabaci (Inoue and Sakurai 2006), and Watermelon silver mottle virus (WSMoV) on Thrips palmi Karny (Chen et al. 2014); and SVNV on N. variabilis (Keough et al. 2016). To date, T. palmi is the only vector reported to transmit GBNV through transmission studies (Lakshmi 1994; Lakshmi et al. 1995; Reddy et al. 1995).

In this study, the effect of GBNV infection on the life history parameters of its vector T. palmi was examined. We further investigated the settling and feeding preference of T. palmi on GBNV-infected and noninfected plants using whole plants and leaf disks. The results of this study will be an added source of information for understanding the effect of plant-infecting viruses on vector.

\section{MATERIALS AND METHODS}

Thrips colony and maintenance. A colony of T. palmi was established from insects collected in cotton (Gossypium sp.) fields at the Indian Agricultural Research Institute, Delhi. The colony was reared on bean pods (Phaseolus vulgaris) in a glass jar (approximately $14.5 \mathrm{~cm}$ in height and approximately $11 \mathrm{~cm}$ in diameter), maintained at $25 \pm 0.5^{\circ} \mathrm{C}$ with 60 to $70 \%$ relative humidity and a photoperiod of $16 \mathrm{~h}$ of light and $8 \mathrm{~h}$ of darkness. For obtaining the cohorts of first-instar larvae, adult females were allowed to lay eggs on a bean pod for $24 \mathrm{~h}$. Fresh bean pods were introduced daily as the food source and oviposition site. Newly emerged first-instar larvae were used for subsequent experiments.

Virus maintenance. Tomato plants that exhibited symptoms of GBNV infection were collected from tomato farms at Coimbatore, Tamil Nadu, India. The infection status of GBNV was confirmed by direct antigen-coated enzyme-linked immunosorbent assay (DACELISA) (Jain et al. 2005) and reverse-transcription polymerase chain reaction (RT-PCR) (Holker et al. 2017). The virus was further maintained in 'Pusa Komal' cowpea by alternating mechanical and thrips inoculation to prevent the development of nontransmissible mutants by thrips. The method developed by Mandal et al. (2008) was adopted for the mechanical inoculation of GBNV into the seedlings of cowpea. For thrips inoculation, freshly emerged firstinstar larvae were allowed to feed on the GBNV-infected cowpea leaf for $24 \mathrm{~h}$, after which the larvae were reared on bean pods until the adult stage. The infected adult thrips were used to inoculate the healthy cowpea seedlings. Successful transmission of GBNV was confirmed by DAC-ELISA and RT-PCR. Only after confirmation of GBNV infection were the cowpea seedlings with severe viral symptoms used as the virus source for subsequent experiments. The groundnut (KRG-1) and tomato seedlings were also mechanically inoculated with GBNV for conducting settling and feeding preference assay. All plants that were used in the experiments were grown from seed.

Acquisition of GBNV by $\boldsymbol{T}$. palmi. Newly emerged cohorts of first-instar larvae from the synchronized rearing were transferred from the bean pods onto GBNV-infected cowpea leaflets in a Petri dish ( $9 \mathrm{~cm}$ in diameter; BD Falcon) with a fine moist brush. The larvae were allowed to acquire the virus with an acquisition access period (AAP) of $24 \mathrm{~h}$. A small piece of filter paper was placed at the bottom of the Petri dish to absorb any excess moisture. To prevent the escape of thrips, the Petri dishes were sealed with Parafilm
(Pechiney Plastic Packaging). The virus-fed larvae were then transferred individually onto a virus-free cowpea leaf disk placed in a $1.5-\mathrm{ml}$ transparent microcentrifuge tube. The larvae were allowed to grow into adults within the $1.5-\mathrm{ml}$ centrifuge tubes by replacing each leaf disk daily with a fresh one.

Detection of GBNV in $T$. palmi and plant samples. To check whether thrips acquired the virus, larvae fed on GBNVinfected leaflets were analyzed individually by DAC-ELISA using polyclonal antiserum against the recombinant nucleocapsid protein of GBNV described by Jain et al. (2005), with slight modifications in centrifugation and antiserum dilution. Thrips specimens were ground in $100 \mu \mathrm{l}$ of coating buffer containing $2 \%$ polyvinyl pyrrolidone (molecular weight 40,000) with a handheld motorized homogenizer. Infected leaves were ground at 1:1 dilution (wt/vol) in coating buffer followed by centrifugation at 12,000 rpm (Eppendorf Refrigerated Centrifuge 5417R) for $2 \mathrm{~min}$ at $4^{\circ} \mathrm{C}$. Homogenate prepared from healthy leaves of respective plant species was used as the negative control. Antiserum was used at 1:200 (for thrips) and 1:500 (for plant leaves) dilution. Antirabbit immunoglobulin G-alkaline phosphatase conjugate (Sigma-Aldrich) was used at 1: 5,000 dilution. The absorbance values were read at $405 \mathrm{~nm} 1 \mathrm{~h}$ after addition of substrate ( $p$-nitrophenyl phosphate at $0.5 \mathrm{mg} / \mathrm{ml}$ ) (Sigma-Aldrich). Furthermore, to check whether the adults transmitted the virus, potentially viruliferous adults were given an inoculation access period (IAP) of $48 \mathrm{~h}$ on healthy Pusa Komal cowpea seedlings and success of thrips inoculation of the plants was assessed by DAC-ELISA and RT-PCR at 5 to 8 days post-IAP. The total RNA was extracted from the plant tissues using RiboZol RNA Extraction Reagent (AMRESCO) according to the manufacturer's directions, and RT-PCR was carried out using the one-step RT-PCR kit (Thermo Scientific), RNA template, and N-gene specific primer pair for GBNV, Gs1F (5'-ATGGTTGAAAAGAGCAAGAAT GATGC- $\left.3^{\prime}\right)$ and GWs1R (5'-CTTCTT(A/T)GA(A/G)TGT(AC/T) CACCATA(A/G)TCATCC-3'), (Holkar et al. 2017). RT was carried out in a $10-\mu \mathrm{l}$ reaction at $42^{\circ} \mathrm{C}$ for $1 \mathrm{~h}$ and stopped with incubation at $70^{\circ} \mathrm{C}$ for $5 \mathrm{~min}$. Furthermore, polymerase chain reaction (PCR) amplification was performed in a $25-\mu$ reaction using an Eppendorf mastercycler pro 4095-4015 (Eppendorf) programmed for $2 \mathrm{~min}$ at $94^{\circ} \mathrm{C}$ for initial denaturation; followed by 30 cycles of $30 \mathrm{~s}$ at $94^{\circ} \mathrm{C}, 30 \mathrm{~s}$ at $55^{\circ} \mathrm{C}$, and $30 \mathrm{~s}$ at $72^{\circ} \mathrm{C}$; with a further $7 \mathrm{~min}$ at $72^{\circ} \mathrm{C}$ after the last cycle for the final extension. Amplified PCR products were analyzed by agarose gel electrophoresis using $0.8 \%$ gel and $1 \times$ Tris-acetate EDTA buffer.

Effect of GBNV on the preadult mortality and development period of T. palmi. To determine the effects of GBNV on T. palmi preadult mortality and the developmental period, newly emerged first-instar larvae were given a 24-h AAP on GBNV-infected cowpea leaflets. Equal numbers of larvae were fed on the healthy cowpea leaflets for $24 \mathrm{~h}$ as a control $(n=40$ each for preadult mortality and $n=10$ each for developmental period per experiment). The viruliferous and nonviruliferous larvae were transferred and reared individually on healthy cowpea leaf disks in 1.5-ml transparent microcentrifuge tubes. The mortality and developmental time were checked every $24 \mathrm{~h}$ until the larvae reached the adult stage. Each leaf disk was replaced daily with a fresh one. The experiment was repeated independently four times under the same conditions as mentioned above.

Effect of GBNV on the adult longevity of $\boldsymbol{T}$. palmi. To compare the effect of GBNV on the longevity of $T$. palmi, newly enclosed viruliferous and nonviruliferous adults $(n=10$ each per experiment) were reared individually on healthy cowpea leaf disks in 1.5-ml transparent microcentrifuge tubes. The longevity was scored at 24-h intervals and each leaf disk was replaced daily with a fresh one. The observation continued until the death of the adult thrips. The experiment was repeated independently four times under the same conditions as mentioned earlier.

Effect of GBNV on the fecundity of T. palmi. To compare the effect of GBNV on the fecundity of T. palmi, newly emerged viruliferous and nonviruliferous female adults were individually 
reared in glass jars containing bean pods as food source and were allowed to lay eggs on the pods ( $n=5$ per experiment). Each bean pod was replaced by a fresh one on a daily basis. The bean pods exposed to the adult thrips were incubated for 3 to 5 days for the eggs to hatch. This process was continued until the thrips died. The fecundity was determined as the number of first-instar larvae that hatched successfully by counting the number of emerged larvae (de Vries et al. 2004; Ogada et al. 2013; Wijkamp et al. 1996) for each individual adult throughout its lifetime. The average lifetime fecundity was calculated by summation of all the daily fecundity recorded throughout the lifetime of the individual thrips used for each treatment. The experiment was repeated independently four times under the same conditions.

Settling and feeding preference of $T$. palmi toward GBNV-infected and healthy plants. Virus-free adults were used to examine the settling and feeding preference toward GBNVinfected or noninfected plants. The experiment was carried out using three different host plants: (i) cowpea (Pusa Komal) wholeplant and leaf disk assay, (ii) groundnut (KRG-1) leaf disk assay, and (iii) tomato leaf disk assay. For the whole-plant assay, GBNVinfected and virus-free cowpea seedlings were placed at an equal distance from the center in a transparent acrylic cage $(22 \mathrm{~cm}$ in length by $22 \mathrm{~cm}$ in breadth by $22 \mathrm{~cm}$ in height). For the leaf-disk assay, the test leaf disks ( $22 \mathrm{~mm}$ in diameter) were obtained separately from GBNV-infected and virus-free leaves. The test leaf disks were placed at the center of the Petri dish (100 by $15 \mathrm{~mm}$; BD Falcon) at equal distance from each other. For easy handling, adult thrips were first immobilized by keeping them at $4^{\circ} \mathrm{C}$ for 10 to $15 \mathrm{~min}$. Twenty adult thrips were randomly selected and introduced at the center of the test arena, where the whole test plants and leaf disks were kept. The choice assay was recorded by counting the number of thrips present on each whole plant and leaf disk at different time intervals $(3,6,12,24$, and $48 \mathrm{~h})$ after they were introduced into the test arena. The experiment was repeated independently four times under the same conditions as mentioned above.

Statistical analysis. The experimental data were analyzed by subjecting to mixed-model analysis of variance (ANOVA), taking replication as the random factor and virus feeding as the fixed factor crossed with replication. In all cases, data were analyzed using one-way ANOVA with mean as unit of analysis.

\section{RESULTS}

Effect of GBNV on the preadult mortality and development period of T. palmi. Preadult mortality was subdivided into larval and pupal (prepupa and pupa) mortality. No significant differences were observed in larval $\left(\mathrm{F}_{(1,6)}=0.67 ; P=0.45\right)$ and pupal $\left(\mathrm{F}_{(1,6)}=0.07 ; P=0.8\right)$ mortality between GBNV-infected and healthy thrips. However, mortality was toward the higher side in both GBNV-infected and healthy thrips during the larval stage than the pupal stage (Fig. 1A). The observed larval mortality in healthy larvae was $41.7 \pm 0.96 \%$ (mean \pm standard error [SE]) and that of GBNV-infected larvae was $38.3 \pm 3.97 \%$, and the observed healthy pupal mortality was $17.5 \pm 2.85 \%$ and that of GBNV-infected pupae was $16.7 \pm 1.36 \%$.

The developmental period of the GBNV-infected first-instar larvae was significantly shorter $(P=0.0005)$ than that of their healthy counterparts (Table 1). However, no significant difference
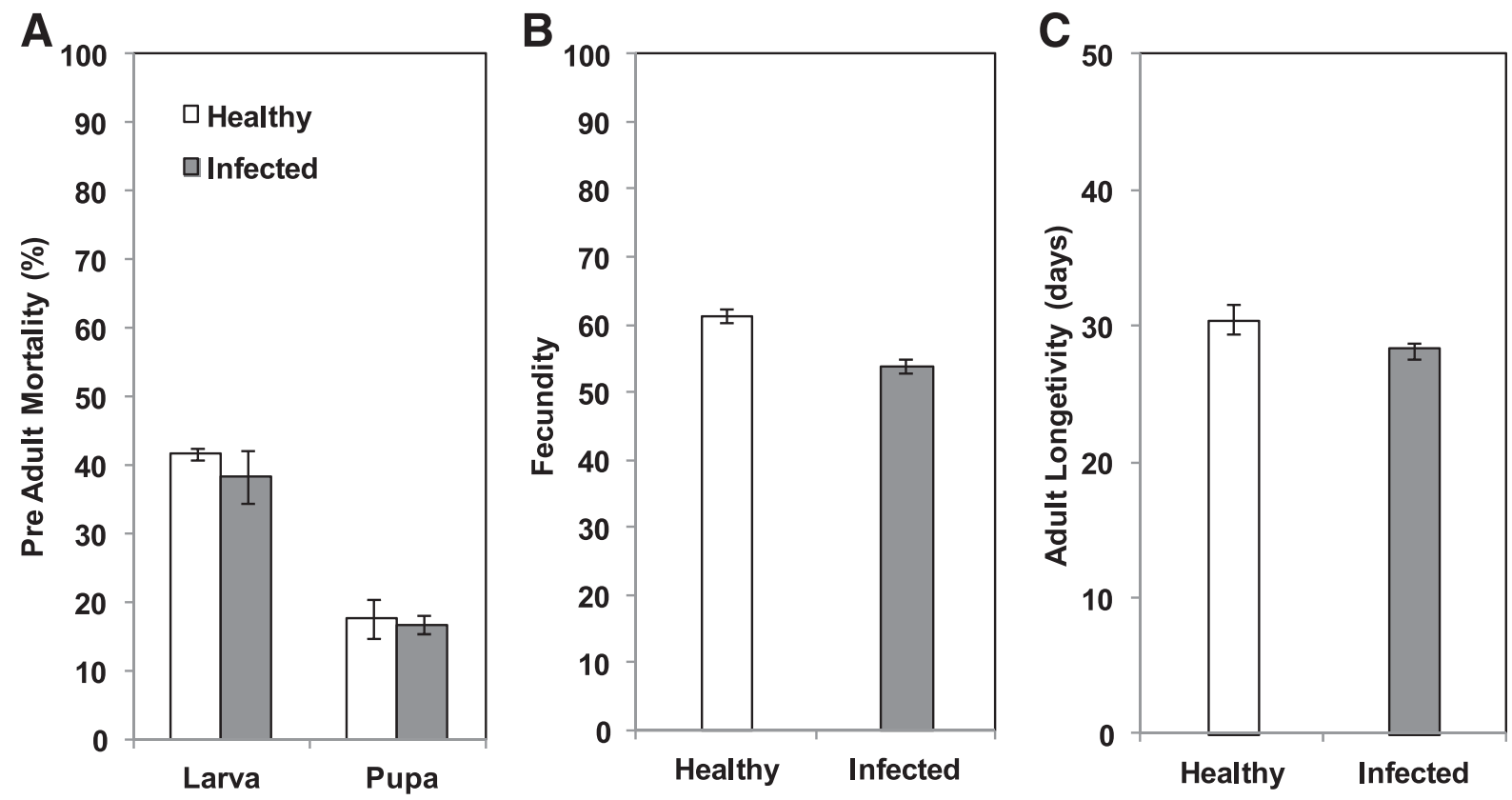

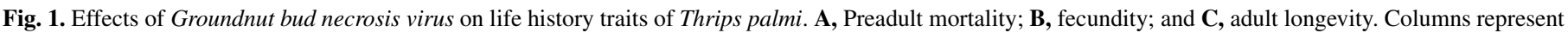
mean values and line bars indicate standard error.

TABLE 1. Effect of Groundnut bud necrosis virus (GBNV) on developmental period of different life stages of Thrips palmi

\begin{tabular}{|c|c|c|c|c|c|}
\hline & \multirow[b]{2}{*}{$n$} & \multicolumn{4}{|c|}{ Developmental period in days $(\text { mean } \pm \mathrm{SE})^{\mathrm{a}}$} \\
\hline & & First instar & Second instar & Pupal stageb & Egg to adult \\
\hline Healthy & 40 & $3.13 \pm 0.03$ & $2.88 \pm 0.08$ & $3.95 \pm 0.12$ & $14.78 \pm 0.17$ \\
\hline GBNV-infected & 40 & $2.53 \pm 0.09$ & $2.85 \pm 0.17$ & $3.55 \pm 0.05$ & $13.6 \pm 0.17$ \\
\hline$P$ value ${ }^{\mathrm{c}}$ & $\ldots$ & $0.0005 * * *$ & 0.9 & $0.02 *$ & $0.002 * *$ \\
\hline
\end{tabular}

a Mean values \pm standard error $(\mathrm{SE})$ represented here came from four replicates of 10 insects each.

b Both prepupa and pupa.

c Asterisks: *,**, and *** indicate $P \leq 0.05,0.01$, and 0.001 , respectively. 
was observed between the GBNV-infected and healthy thrips during the second larval instar. Further, the developmental period was again significantly shorter during the pupal (prepupa and pupa) stage in the GBNV-infected $(P=0.02)$ than the healthy thrips. There was an overall statistically significant difference between the developmental period of GBNV-infected and healthy thrips, wherein the infected thrips had a shorter developmental period $(P=$ 0.002) (Table 1).

Effect of GBNV on the fecundity of T. palmi. Fecundity was determined by counting the number of emerged first-instar larvae. The fecundity of the GBNV-infected female thrips was lower as compared with the virus-free thrips. The mean fecundity of GBNV-infected and virus-free female thrips was $56.7 \pm 3.52$ and $61.5 \pm 0.93$ (mean $\pm \mathrm{SE}$ ) larvae, respectively. However, this difference was statistically not significant (Fig. 1B). This suggested that GBNV infection did not affect the fecundity of T. palmi.

Effect of GBNV on the adult longevity of T. palmi. Adult longevity of both GBNV-infected and virus-free thrips was assessed at 24-h intervals. Although the longevity of GBNV-infected adults was shorter $(28.5 \pm 0.29$ days $)$ than that of virus-free adults $(30.45 \pm$ 1 days) (mean $\pm \mathrm{SE}$ ), no significant difference was observed between the adult longevity of GBNV-infected and virus-free thrips (Fig. 1C). Our results suggested that GBNV infection did not affect the adult longevity of T. palmi.
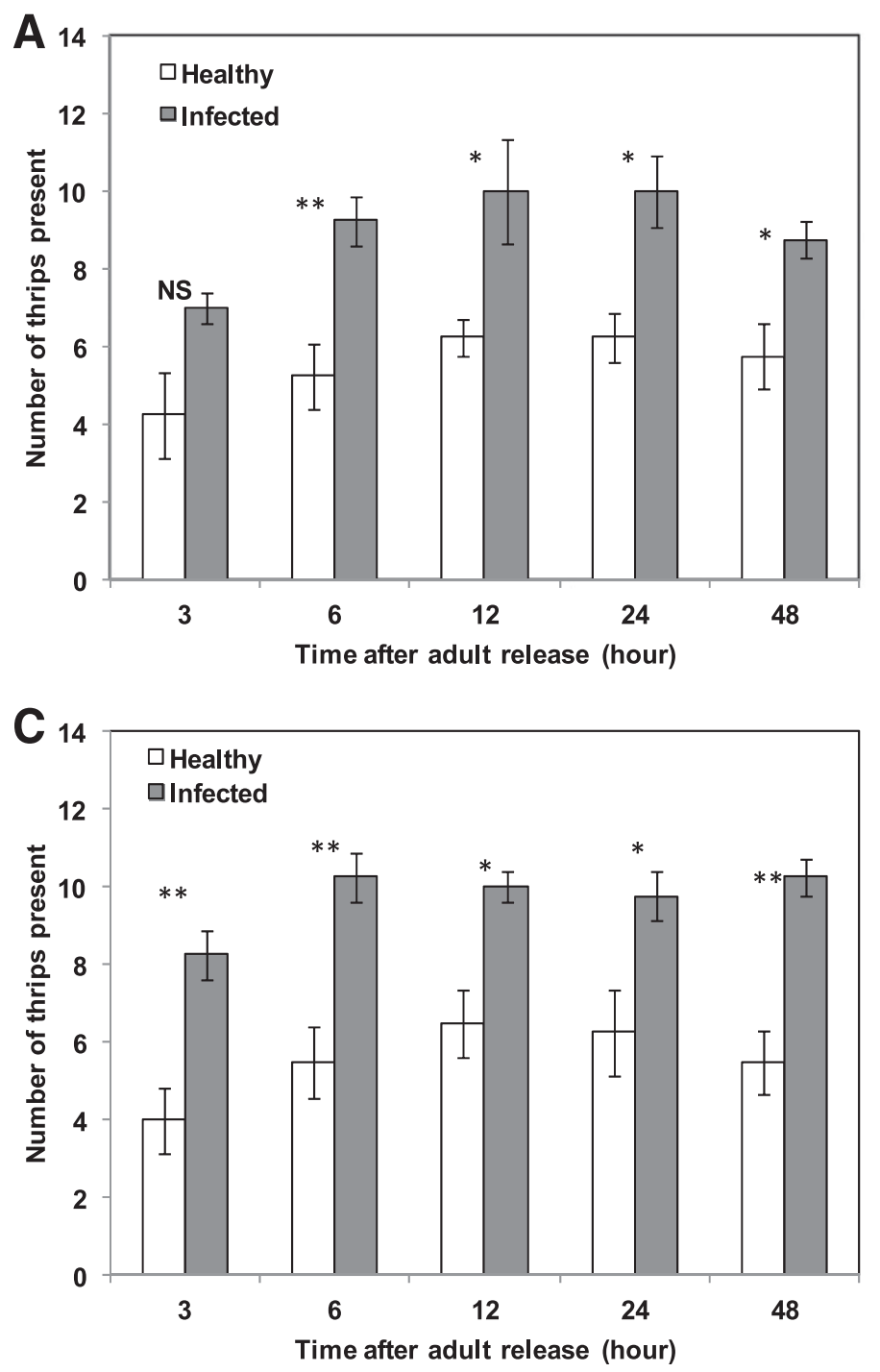

Settling and feeding preference of $T$. palmi toward GBNV-infected and healthy plants. The choice assay on the settling and feeding preference of T. palmi for GBNV-infected and healthy plants was carried out using whole plants and leaf disks. The assay was conducted by introducing newly emerged virus-free adults into the test arena (acrylic cage and Petri dish). The numbers of thrips present on both the GBNV-infected and healthy whole plants and leaf disks at different time intervals $(3,6,12,24$, and $48 \mathrm{~h})$ were recorded. Significantly more thrips were found attracted toward the GBNV-infected cowpea plant than toward the healthy cowpea plants at all time intervals except $3 \mathrm{~h}$ (Fig. 2A). Similarly, more thrips were attracted toward GBNV-infected cowpea, groundnut, and tomato leaf disks than the healthy leaf disks of these plants at all time intervals examined (Fig. 2B, C, and D).

\section{DISCUSSION}

The effects of plant-infecting viruses on their vectors differ across virus-vector combinations (Moreno-Delafuente et al. 2013; Nault 1997). Although several studies have been carried out on the effects of TSWV on its primary vector (F. occidentalis) and other vector species, specific interaction studies need to be conducted to ascertain the effect of other tospoviruses on their vectors. This is due to a range of contradictory results that have been reported (Medeiros
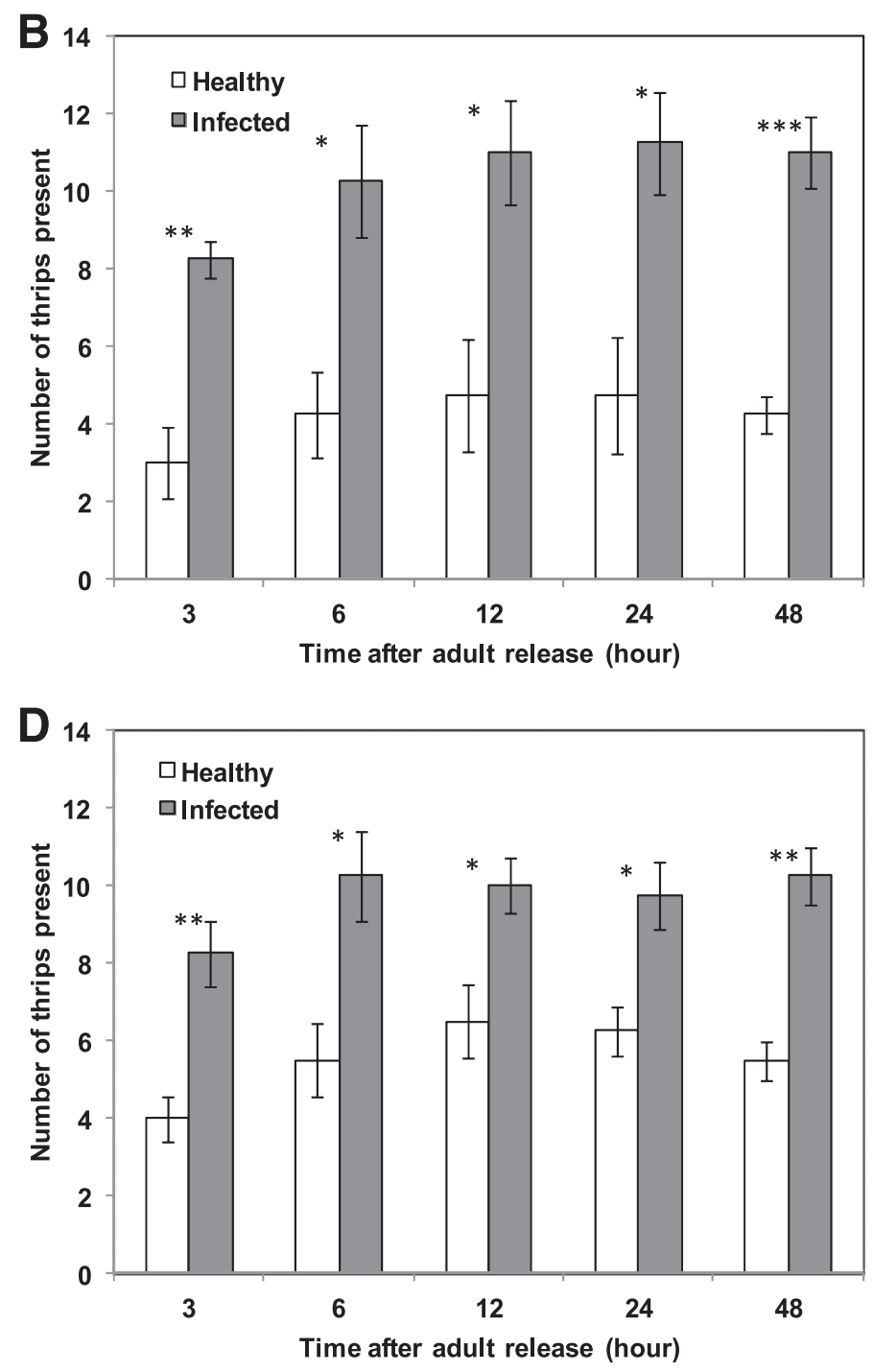

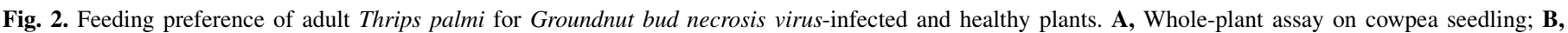

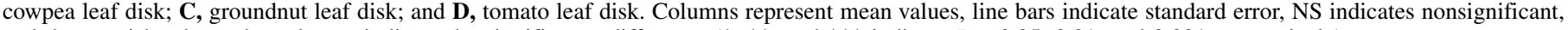
and the asterisks above the columns indicate the significance difference ${ }^{*}$, **, and *** indicate $P \leq 0.05,0.01$, and 0.001 , respectively). 
et al. 2004; Nault 1994; Ogada and Poehling 2015; Ogada et al. 2013; Rotenberg et al. 2015). Infection, replication, and pathological effects of TSWV, Impatient necrotic spot virus, and IYSV have been reported in several thrips vector species (Birithia et al. 2013; Moritz et al. 2004; Ullman et al. 1992, 1993). Thus, multiplication of a virus might interfere with several physiological processes and it could either positively or negatively affect its vector fitness.

Our study showed that GBNV infection affects developmental time of its vector, T. palmi (Table 1). The total developmental time from first larval instar to adult shows a significant difference between the GBNV-infected and healthy thrips, wherein GBNVinfected thrips had a shorter developmental period. However, if there was a true biological influence of GBNV on T. palmi developmental time, we expected to observe a significant difference at all of the developmental stages and not just at first larval instar and pupal stages. Because the difference in the overall developmental time was minimal, the effect of natural variations in developmental time of T. palmi cannot be ruled out. Shortening of developmental time may facilitate the early transmission of the virus to other plants by adult thrips and, thus, can potentially enhance the spread of the virus. Previous reports have also mentioned the reduction in developmental time in TSWVinfected F. occidentalis (Ogada and Poehling 2015; Stumpf and Kennedy 2007). In contrast, delay in developmental time has also been reported following TSWV infection of its vector, $F$. fusca (Shrestha et al. 2012; Stumpf and Kennedy 2005). In addition, no effects on developmental times have been reported in TSWV infection of its vectors, T. tabaci (Inoue and Sakurai 2006) and F. occidentalis (Wijkamp et al. 1996), and WSMoV infection on its vector, T. palmi (Chen et al. 2014). Although it appears that the infection of GBNV affects its vector (T. palmi) by reducing its developmental times, further investigation is warranted to study the influence of GBNV on the life history traits of T. palmi such as developmental period, larval and pupal mortality, fecundity, and adult longevity.

Our study indicates that GBNV infection does not affect the reproductive potential of T. palmi. Though the mean overall number of offspring produced was found to be lower in the virus-infected thrips than their healthy counterparts, the difference was not significant (Fig. 1B). The present finding is consistent with earlier reports that have shown that WSMoV infection does not affect the fecundity of T. palmi (Chen et al. 2014). However, another study has reported a contradictory result in a different thrips species, $F$. fusca, infected with TSWV (Shrestha et al. 2012). The differences between various reports could be due to different tospoviruses, different vector species, or other as-yet-unknown experimental factors. Furthermore, it also was observed that GBNV infection has no significant effect on the preadult mortality and the adult longevity of its vector, T. palmi (Fig. 1A and C). This finding is similar to those of earlier reports on the influence of WSMoV infection on T. palmi (Chen et al. 2014) and TSWV on F. occidentalis (Wijkamp et al. 1996). However, in our study, the effects of GBNV on its vectors in relation to mortality, fecundity, and longevity were insignificant when compared with virus-free thrips (Fig. 1A, B, and C).

Many plant viruses depend on insect vectors for their transmission. The availability and abundance of the vector species with relation to infected plants and their dispersal are important factors in spreading the virus (Mauck et al. 2012). Earlier studies have reported that insect vectors are more attracted toward plants infected with viruses (Chen et al. 2014; Maris et al. 2004; Mauck et al. 2010, 2012; Medina-Ortega et al. 2009). For virus transmission to occur, its vector must first move and get attracted to infected plants. This attraction can be mediated chemically through volatile organic molecules (Maris et al. 2004; Mauck et al. 2012) and also by visual cues (Döring et al. 2009; Mauck et al. 2012). Following attraction toward the infected plants, the vector must settle and start feeding to acquire the virus (Mauck et al. 2012). However, depending on the nature of the virus, the time required for feeding to acquire the virus may differ, and persistently transmitted viruses need sustained feeding to acquire the virus (Mauck et al. 2012). However, in the case of tospoviruses, which are also persistently transmitted viruses, even a low AAP of 5 min in the first larval instar results in the ability of thrips to transmit the virus when they reach the adult stage (Lakshmi 1994; Lakshmi et al. 1995). Unless the first larval instar acquires the virus, the emerging adults cannot successfully transmit the virus (Whitfield et al. 2005). In our study of the settling and feeding choice assay of T. palmi between GBNV-infected and healthy leaves, it was observed that T. palmi insects were more attracted to the GBNV-infected cowpea plants and leaf disks of all three test host plants than to the healthy cowpea whole plant and all the healthy leaf disks (Fig. 2A, B, C, and D). This is in agreement with earlier findings which reported that plants infected with TSWV attract more F. occidentalis thrips than noninfected plants (Bautista et al. 1995; Maris et al. 2004; Ogada et al. 2013), and plants infected with WSMoV attract more T. palmi than the noninfected plants (Chen et al. 2014). Thus, the attractiveness and preference of adult thrips toward the infected plant can act as catalyst for spreading the virus to noninfected standing crops or plants. As adult thrips lay eggs on the infected plants, the newly emerged larvae will feed on the infected leaf and acquire the virus and later transmit the virus when they become adults.

Information about GBNV interaction with its vector and the mechanism of replication and virus transmission is not completely understood, and further studies are required to elucidate the functional aspects of GBNV and its transmission by T. palmi. Moreover, our results provide insights regarding the early events of virus-vector interaction leading to successful virus transmission.

\section{ACKNOWLEDGMENTS}

We thank A. Pal for laboratory assistance. This research was supported by Indian Council of Agricultural Research-funded research project "Outreach programme on management of sucking pests in horticultural crops" (ORP-SP), DU-DST PURSE, and a University of Delhi faculty research grant.

\section{LITERATURE CITED}

Akram, M., and Naimuddin. 2010. First report of Groundnut bud necrosis virus infecting pea (Pisum sativum) in India. New Dis. Rep. 21:10.

Bautista, R. C., Mau, R. F. L., Cho, J. J., and Custer, D. M. 1995. Potential of tomato spotted wilt tospovirus plant nests in Hawaii as virus reservoirs for transmission by Frankliniella occidentalis (Thysanoptera, Thripidae). Phytopathology 85:953-958.

Belliure, B., Janssen, A., Maris, P. C., Peters, D., and Sabelis, M. W. 2005. Herbivore arthropods benefit from vectoring plant viruses. Ecol. Lett. 8: 70-79.

Bhat, A. I., Jain, R. K., Varma, A., and Lal, S. K. 2002. Nucleocapsid protein gene sequence studies suggest that soybean bud blight is caused by a strain of Groundnut bud necrosis virus. Curr. Sci. 82:1389-1392.

Birithia, R., Subramanian, S., Pappu, H. R., Muthomi, J., and Narla, R. D. 2013. Analysis of Iris yellow spot virus replication in vector and non-vector thrips species. Plant Pathol. 62:1407-1414.

Chen, W.-T., Tseng, C.-H., and Tsai, C.-W. 2014. Effect of Watermelon silver mottle virus on the life history and feeding preference of Thrips palmi. PLoS One 9:e102021.

Childers, C. C., and Achor, D. S. 1995. Thrips feeding and ovipositional injuries to economic plants, subsequent damage and host responses to infestation. Pages 31-51 in: Thrips Biology and Management. B. L. Parker, M. Skinner, and T. Lewis, eds. Plenum Press, New York.

Childers, C. C., and Bullock, R. C. 1999. Controlling Frankliniella bispinosa (Thysanoptera: Thripidae) on Florida citrus during bloom and increased fruit set on navel and 'Valencia' oranges. Fla. Entomol. 82:410-424.

Culbreath, A. K., Todd, J. W., and Brown, S. L. 2003. Epidemiology and management of tomato spotted wilt in peanut. Annu. Rev. Phytopathol. 41: 53-75.

de Vries, E. J., Jacobs, G., Sabelis, M. W., Menken, S. B. J., and Breeuwer, J. A. J. 2004. Diet dependent effects of gut bacteria on their insect host: The symbiosis of Erwinia sp. and western flower thrips. Proc. R. Soc. Lond. B Biol. Sci. 271:2171-2178. 
Döring, T. F., Archetti, M., and Hardie, J. 2009. Autumn leaves seen through herbivore eyes. Proc. Biol. Sci. 276:121-127.

German, T. L., Ullman, D. E., and Moyer, J. W. 1992. Tospoviruses: Diagnosis, molecular biology, phylogeny, and vector relationships. Annu. Rev. Phytopathol. 30:315-348.

Goldbach, R., and Peters, D. 1994. Possible causes of the emergence of Tospovirus diseases. Semin. Virol. 5:113-120.

Heming, B. S. 1993. Structure, function, ontogeny and evolution of feeding in thrips (Thysanoptera). Pages 3-41 in: Functional Morphology of Insect Feeding. C. W. Schaefer and R. B. Leschen, eds. Thomas Say Publications in Entomology, Entomological Society of America, Lanham, MD.

Hogenhout, S. A., Ammar, E. D., Whitfield, A. E., and Redinbaugh, M. G. 2008. Insect-vector interactions with persistently transmitted viruses. Annu. Rev. Phytopathol. 46:327-359.

Holkar, S. K., Kumar, R., Yogita, M., Katiyar, A., Jain, R. K., and Mandal, B. 2017. Diagnostic assays for two closely related Tospovirus species, Watermelon bud necrosis virus and Groundnut bud necrosis virus and identification of new natural hosts. J. Plant Biochem. Biotechnol. 26:45-51.

Inoue, T., Murai, T., and Natsuaki, T. 2010. An effective system for detecting Iris yellow spot virus transmission by Thrips tabaci. Plant Pathol. 59: 422-428.

Inoue, T., and Sakurai, T. 2006. Infection of Tomato spotted wilt virus (TSWV) shortens the life span of thelytokous Thrips tabaci (Thysanoptera: Thripidae). Appl. Entomol. Zool. (Jpn.) 41:239-246.

Jacobson, A. L., and Kennedy, G. G. 2013. Specific insect-virus interactions are responsible for variation in competency of different Thrips tabaci isolines to transmit different tomato spotted wilt virus isolates. PLoS One 8:e54567.

Jain, R. K., Pande, A., and Mandal, B. 2005. Immonodiagnosis of groundnut and watermelon bud necrosis virus using polyclonal antiserum to recombinant nucleocapsid protein of Groundnut bud necrosis virus. J. Virol. Methods 130:162-164.

Jain, R. K., Umamaheswaran, K., Bhat, A. I., Thien, H. X., and Ahlawat, Y. S. 2002. Necrosis disease on cowpea, mungbean and tomato is caused by Groundnut bud necrosis virus. Ind. Phytopathol. 55:354.

Jiu, M., Zhou, X.-P., Tong, L., Xu, J., Yang, X., Wan, F. H., and Liu, S.-S. 2007. Vector-virus mutualism accelerates population increase of an invasive whitefly. PLoS One 2:e182.

Jones, D. R. 2005. Plant viruses transmitted by thrips. Eur. J. Plant Pathol. 113: 119-157.

Keough, S., Han, J., Shuman, T., Wise, K., and Nachappa, P. 2016. Effects of Soybean vein necrosis virus on life history and host preference of its vector, Neohydatothrips variabilis, and evaluation of vector status of Frankliniella tritici and Frankliniella fusca. J. Econ. Entomol. 109:1979-1987

Lakshmi, K. V. 1994. Transmission and ecology of Thrips palmi Karny, the vector of peanut bud necrosis virus. Ph.D. thesis, Andhra Pradesh Agricultural University, Rajendranagar, Hyderabad, India. Online publication. http://oar.icrisat.org/338/1/61328.pdf

Lakshmi, K. V., Wightman, J. A., Reddy, D. V. R., Ranga-Rao, G. V., Buiel, A. A. M., and Reddy, D. D. R. 1995. Transmission of Peanut bud necrosis virus by Thrips palmi in India. Pages 179-184 in: Thrips Biology and Management. B. L. Parker, M. Skinner, and T. Lewis, eds. Plenum Press, New York.

Lewis, T. 1973. Thrips: Their Biology, Ecology and Economic Importance. Academic Press Inc., London, New York.

Mandal, B., Csinos, A. S., Martinez-Ochoa, N., and Pappu, H. R. 2008. A rapid and efficient inoculation method for Tomato spotted wilt tospovirus. J. Virol. Methods 149:195-198.

Maris, P. C., Joosten, N. N., Goldbach, R. W., and Peters, D. 2004. Tomato spotted wilt virus infection improves host suitability for its vector Frankliniella occidentalis. Phytopathology 94:706-711.

Mauck, K., Bosque-Pérez, N., Eigenbrode, S. D., De Moraes, C., and Mescher, M. 2012. Transmission mechanisms shape pathogen effects on host-vector interactions: Evidence from plant viruses. Funct. Ecol. 26:1162-1175.

Mauck, K. E., De Moraes, C. M., and Mescher, M. C. 2010. Deceptive chemical signals induced by a plant virus attract insect vectors to inferior hosts. Proc. Natl. Acad. Sci. USA 107:3600-3605.

Medeiros, R. B., Resende, R. O., and Avila, A. C. 2004. The plant virus Tomato spotted wilt tospovirus activates the immune system of its main insect vector, Frankliniella occidentalis. J. Virol. 78:4976-4982.

Medina-Ortega, K. J., Bosque-Perez, N. A., Ngumbi, E., Jiménez-Martínez, E. S., and Eigenbrode, S. D. 2009. Rhopalosiphum padi (Hemiptera, Aphididae) responses to volatile cues from Barley yellow dwarf virusinfected wheat. Environ. Entomol. 38:836-845.

Moreno-Delafuente, A., Garzo, E., Moreno, A., and Fereres, A. 2013. A plant virus manipulates the behavior of its whitefly vector to enhance its transmission efficiency and spread. PLoS One 8:e61543.

Moritz, G., Kumm, S., and Mound, L. 2004. Tospovirus transmission depends on thrips ontogeny. Virus Res. 100:143-149.
Nault, L. R. 1994. Transmission biology, vector specificity and evolution of planthopper-transmitted plant viruses. Pages 429-448 in: Planthoppers: Their Ecology and Management. R. F. Denno and T. J. Perfect, eds. Chapman and Hall Inc., New York.

Nault, L. R. 1997. Arthropod transmission of plant virus: A new synthesis. Ann. Entomol. Soc. Am. 90:521-541.

Ogada, P. A., Maiss, E., and Poehling, H. M. 2013. Influence of Tomato spotted wilt virus on performance and behaviour of western flower thrips (Frankliniella occidentalis). J. Appl. Entomol. 137:488-498.

Ogada, P. A., and Poehling, H. M. 2015. Sex-specific influences of Frankliniella occidentalis (Western Flower Thrips) in the transmission of Tomato spotted wilt virus (Tospovirus). J. Plant Dis. Prot. 122:264-274.

Pappu, H. R., Jones, R. A. C., and Jain, R. K. 2009. Global status of Tospovirus epidemics in diverse cropping systems: Successes achieved and challenges ahead. Virus Res. 141:219-236.

Pearce, M. 2005. 2004 Georgia Plant Disease Loss Estimates. University Georgia Cooperative Extension Service, Georgia.

Persley, D. M., Thomas, J. E., and Sharman, M. 2006. Tospoviruses-An Australian perspective. Australas. Plant Pathol. 35:161-180.

Raja, P., and Jain, R. K. 2006. Molecular diagnosis of Groundnut bud necrosis virus causing bud blight of tomato. Ind. Phytopathol. 59:359-362.

Reddy, D. V. R., Buiel, A. A. M., Satyanarayana, T., Dwivedi, S. L., Reddy, A. S., Ratna, A. S., Lakshmi, K. V., Rao, G. V. R., Naidu, R. A., and Wightman, J. A. 1995. Peanut bud necrosis virus disease: An overview. Pages 3-7 in: Recent Studies on Peanut Bud Necrosis Disease. ICRISAT Conf. Pap. No. CP 994. A. A. M. Buiel, J. E. Parlevliet, and J. M. Lenne, eds. ICRISAT Asia Centre, Hyderabad, India.

Riley, D. G., Joseph, S. V., Srinivasan, R., and Diffie, S. 2011. Thrips vectors of tospoviruses. J. Integr. Pest Manage. 2:I1-I10.

Rotenberg, D., Jacobson, A. L., Schneweis, D. J., and Whitfield, A. E. 2015. Thrips transmission of tospoviruses. Curr. Opin. Virol. 15:80-89.

Sherwood, J. L., German, T. L., Moyer, J. W., Ullman, D. E., and Whitfield, A. E. 2000. Tomato spotted wilt. Pages 1030-1031 in: Encyclopedia of Plant Pathology. O. C. Maloy and T. D. Murray, eds. John Wiley and Sons, New York.

Shrestha, A., Srinivasan, R., Riley, D. G., and Culbreath, A. K. 2012. Direct and indirect effects of a thrips-transmitted Tospovirus on the preference and fitness of its vector, Frankliniella fusca. Entomol. Exp. Appl. 145: 260-271.

Singh, A. B., and Srivastava, S. K. 1995. Status and control strategy of peanut bud necrosis disease in Uttar Pradesh. Pages 65-68 in: Recent Studies on Peanut Bud Necrosis Disease. A. A. M. Buiel, J. E. Parlevliet, and J. M. Lenne, eds. ICRISAT Asia Centre, Hyderabad, India.

Singh, R. B., Srivastava, K. K., Pandey, S. K., and Paul Khurana, S. M. 1997. Assessment of yield losses due to potato stem necrosis disease. Indian J. Virol. 13:135-137.

Stafford, C. A., Gregory, P. W., and Ullman, D. E. 2011. Infection with a plant virus modifies vector feeding behavior. Proc. Natl. Acad. Sci. USA 108: 9350-9355.

Stumpf, C. F., and Kennedy, G. G. 2005. Effects of Tomato spotted wilt virus (TSWV) isolates, host plants, and temperature on survival, size, and development time of Frankliniella fusca. Entomol. Exp. Appl. 114:215-225.

Stumpf, C. F., and Kennedy, G. G. 2007. Effects of Tomato spotted wilt virus isolates, host plants, and temperature on survival, size, and development time of Frankliniella occidentalis. Entomol. Exp. Appl. 123:139-147.

Thien, X. H., Bhat, A. I., and Jain, R. K. 2003. Mungbean necrosis disease is caused by a strain of Groundnut bud necrosis tospovirus. Ind. Phytopathol. 56:54-60.

Tsuda, S., Fujisawa, I., Ohnishi, J., Hosokawa, D., and Tomaru, K. 1996. Localization of tomato spotted wilt tospovirus in larvae and pupae of the insect vector Thrips setosus. Phytopathology 86:1199-1203.

Ullman, D. E., Cho, J. J., Mau, R. F. L., Westcot, D. M., and Custer, D. M. 1992. Midgut epithelial cells act as a barrier to tomato spotted wilt virus acquisition by adult western flower thrips. Phytopathology 82:1333-1342.

Ullman, D. E., German, T. L., Sherwood, J. L., Westcot, D. B., and Cantone, F. A. 1993. Tospovirus replication in insect vector cells: Immunocytochemical evidence that the nonstructural protein encoded by the S RNA of tomato spotted wilt tospovirus is present in thrips vector cells. Phytopathology 83:456-463.

Whitfield, A. E., Ullman, D. E., and German, T. L. 2005. Tospovirus-thrips interactions. Annu. Rev. Phytopathol. 43:459-489.

Wijkamp, I., Goldbach, R., and Peters, D. 1996. Propagation of tomato spotted wilt virus in Frankliniella occidentalis does neither result in pathological effects nor in transovarial passage of the virus. Entomol. Exp. Appl. 81: 285-292.

Wijkamp, I., van Lent, J., Kormelink, R., Goldbach, R., and Peters, D. 1993. Multiplication of tomato spotted wilt virus in its insect vector Frankliniella occidentalis. J. Gen. Virol. 74:341-349. 